\title{
Aptitude of Vermicompost and Bio-fertilizers on Crop growth, yield and economics of Turmeric (Curcuma longa L.)
}

\author{
Bibhuti Bhusan Sahoo ${ }^{1 *}$, Bibhuti Bhusan Dalei ${ }^{2}$, \\ Amit Phonglosa ${ }^{3}$ and Niranjan Senapati ${ }^{4}$ \\ ${ }^{1}$ Regional Research and Technology Transfer Station (OUAT), \\ Bhawanipatna, Kalahandi, Odisha-766001, India \\ ${ }^{2}$ Regional Research and Technology Transfer Station (OUAT), \\ Semiliguda, Koraput, Odisha-763002, India \\ ${ }^{3}$ Directorate of Extension Education (OUAT), Bhubaneswar, Odisha-751003, India \\ ${ }^{4}$ Centre for Pulses Research, Berhampur, Ganjam, Odisha-766110, India \\ *Corresponding author
}

\begin{abstract}
A B S T R A C T
Keywords

Azospirillum,

Azotobacter,

economics,

turmeric

Article Info

Accepted:

14 May 2020

Available Online:

10 June 2020

Field experiments were an attempt to assess the efficacy of vermicompost, biofertilizers along with inorganic nutrients in turmeric cv. Roma. In a randomized block design, ten treatments with variable recommended dose of fertilizer (60:30:90 kg N, $\mathrm{P}_{2} \mathrm{O}_{5}, \mathrm{~K}_{2} \mathrm{O} \mathrm{ha}^{-1}$ ) along with vermicompost @5 $\mathrm{t} \mathrm{ha}^{-1}$ and biofertilizers (Azospirillum and Azotobacter @10 kg ha ${ }^{-1}$ ) were replicated thrice for the said evaluation. Significantly maximum rhizome yield of $219.2 \mathrm{q} \mathrm{ha}^{-1}$ was obtained with the application of $100 \%$ RDF along with vermicompost and biofertilizers followed by the application of $75 \%$ RDF along with vermicompost and bio-fertilizers with rhizome yield of $206.6 \mathrm{q} \mathrm{ha}^{-1}$. The combination of biofertilizers and vermicompost along with RDF express their supremacy over other nutrient combinations. Application of $100 \%$ RDF with vermicompost and biofertilizers was at par with the application of $75 \%$ RDF along with vermicompost and bio-fertilizers. Hence $25 \%$ of inorganic fertilizers can be replaced with the application of organic fertilizers.
\end{abstract}

\section{Introduction}

Nutrient management is one of the fundamental cultural practices that impact the soil fertility status in addition to plant growth. However, injudicious utility of chemical fertilizer harm the soil health along with entire ecosystem (Chanahan et al., 2018).
Organic manures and bio-fertilizers are the alternative sources of plant nutrition. Intensification of crop production and sustainability of soil fertility status is the sole objective that can be achieved by these biological inputs (Roy et al., 2011). Vermicompost are generally obtained by a non-thermophilic biodegradation of natural 
materials through associations between earthworms and microorganisms (Aira et al., 2002; Sallaku et al., 2009). Under integrated systems, the use of organic manures has adequate scope for organic recycling of biowastes that are produced in situ (Jayanthi et $a l .$, 2009). Furthermore, it has been observed that the use of bio-fertilizers along with balanced and adequate combination of inorganic fertilizers significantly improves morpho-physiological traits, growth parameters and fruit yield in egg plants (Patel et al., 2010). Singh and Sinsinwar, (2006) reported an integrated use of bio-fertilizers and chemical fertilizers facilitates sustainable crop production along with maintenance of soil fertility.

Turmeric (Curcuma longa L.) the "Golden Spice" is an erect oblong rhizome of family Zingiberaceae, which contains carbohydrates $(69.4 \%)$, fats $(5.1 \%)$, proteins $(6.3 \%)$, minerals $(3.5 \%)$ volatile oil $(5.0-6.0 \%)$ and oleoresin (7.9-10.4\%) (Anuradha, et al.,2018). Apart from this it contains high oleoresin and curcumin content, as a consequence used as a food additive (spice), preservative coloring agent, cosmetics, medicinal drug and created abundant export opportunity as reported by Amala et al., (2019). Sasikumar (2005); Bejar (2018) elaborate the importance of turmeric as a medicinal herb, for its anti-inflammatory, anti-cancerous, anti-oxidant, anti-microbial and anti-viral properties, as an antiseptic and in the treatment of diabetes and Alzheimer's diseases. It is one of the customary medicinal plants used in Ayurveda, Unani and Siddha medicine as a conventional remedy for various illnesses arthritis, dysentery, fever, indigestion, infections, inflammation, injuries, jaundice liver issues trauma and wounds. It is taken in to consideration to be the safest herb of choice for all blood problems since it purifies, stimulates and builds blood. The consumption pattern of turmeric is increasing frequently because of its high remedial and dietetic price and there may be infrequently any opportunities of increase in cultivable land. Srinivas et al., (2018), documented, about $76 \%$ of the world turmeric production is from India. India stands in an advanced position by means of producing 11.32 lakh tonnes of turmeric from an area of 2.37 lakh ha with a mean productivity of 4.76 tonnes per ha (Saxena et al., 2018). The productivity of turmeric remains stable from 2012 to till date with a negligible discrepancy from 5.0 to 4.76 tonnes per ha. Odisha ranks $3^{\text {rd }}$ in the area (27.86 thousand ha) and $7^{\text {th }}$ in production (54.50 thousand tonnes), however in case of productivity, the state stands in a completely terrible condition (Saxena et al., 2018). On the other hand, it is estimated that India is expected to have a population of about 1.69 billion and the second biggest urban population ( 0.9 billion) in the world by 2050 . The per capita consumption of turmeric is expected to be about $1.6 \mathrm{~kg}$ with a typical productivity demand of $9350 \mathrm{~kg}$ per ha of turmeric by 2050 (Anonymous, 2015).

To fulfil the requirements of those evergrowing populations and per capita consumption, export, processing and postharvest losses, the present need higher production from a specific unit of land. This needs growth in average productiveness from the same piece of land. Turmeric is extensively cultivated in the tribal-dominated hilly regions of Odisha with utmost usage of indigenous inputs and conventional knowledge, with such a wonderful production technology turmeric was well recognized with their respective localities. The quantity (yield) and quality of turmeric production are related to their genetic and environmental characters. But unvarying applications of synthetic /inorganic fertilizer deteriorate the soil health with a higher degree of qualitative deterioration in a crop like turmeric. 
Inadequate plant nutrition causes extreme disorders in turmeric as well as a significant loss in yield. Higher productivity is viable through quality planting material, balanced nutrition with natural organic manure and optimum soil and plant health management. Peter et al., (2000) have reported turmeric to be an exhaustive crop that responds nicely to the sensible utility of fertilizers and manures. Hence, the applications of organic manure or bio-fertilizer not only lessen the economic losses in crop production but also complement to quality production. Keeping a lot of these in view the present experiment needs to be performed to evaluate the efficacy of inorganic fertilizers, vermicompost and biofertilizers on growth and yield of turmeric (cv. Roma) under the eastern ghat high land zone of Odisha.

\section{Materials and Methods}

\section{Experimental site}

The field experiments were conducted on turmeric cv. Roma at Regional Research \& Technology Transfer Station (OUAT), Semiliguda, Odisha for the duration of kharif 2013-14 to 2015-2016 under eastern ghat high land zone of Odisha. It is located at $18^{\circ} 42^{\prime} \mathrm{N}$ latitude \& $82^{\circ} 30^{\prime} \mathrm{E}$ longitude with an altitude of $884 \mathrm{~m}$ above mean sea level.

The soil characteristics of the experimental site are strong to moderately acidic (PH.4.9) with low to medium organic matter (0.560.61 ) and poor water retentive capacity. These soils are moderately deficient in nitrogen (396-419 kg/ha) and phosphorus (14$17 \mathrm{~kg} / \mathrm{ha}$ ), however, the availability of potassium could be very low i.e. 46.47-59.26 $\mathrm{kg} / \mathrm{ha}$. Micronutrients like boron and molybdenum are enormously deficient in these soils. These soils have low cation exchange capacity with high phosphate and sulphur absorption property and poor in calcium and magnesium.

\section{The climatic situation of the experimental site}

The climatic state of affairs of the experimental site becomes hot and humid, with an annual mean rainfall of $1567 \mathrm{~mm}$, most of which $(90 \%)$ was received at some stage in the month of June to September. The mean summer and iciness temperatures have been $34^{\circ} \mathrm{C}$ and $12^{\circ} \mathrm{C}$ respectively.

\section{Experimental design}

The field experiments were specified in a randomized block design (RBD) with ten treatments consisting of diverse changes of recommended dose of fertilizer (RDF) viz. $\mathrm{T}_{1^{-}}$ Control (No fertilizers), $\mathrm{T}_{2}-0 \% \mathrm{RDF}+\mathrm{Bio}-$ fertilizers $(\mathrm{BF})+$ Vermicompost $(\mathrm{VC}), \mathrm{T}_{3^{-}}$ $25 \% \mathrm{RDF}+\mathrm{BF}+\mathrm{VC}, \mathrm{T}_{4}-50 \% \mathrm{RDF}+\mathrm{BF}+$ $\mathrm{VC}, \mathrm{T}_{5}-75 \% \mathrm{RDF}+\mathrm{BF}+\mathrm{VC}, \mathrm{T}_{6}-100 \% \mathrm{RDF}$ $+\mathrm{BF}+\mathrm{VC}, \mathrm{T}_{7}-25 \% \mathrm{RDF}, \mathrm{T}_{8}-50 \% \mathrm{RDF}, \mathrm{T}_{9^{-}}$ $75 \%$ RDF $\mathrm{T}_{10}-100 \% \mathrm{RDF}$ and replicated thrice. The recommended dose of fertilizers was 60:30:90 kg N, $\mathrm{P}_{2} \mathrm{O}_{5}, \mathrm{~K}_{2} \mathrm{O}$ ha $^{-1}$. Whereas the dose of vermicompost was $5 \mathrm{t} \mathrm{ha}^{-1}$ and biofertilizers $10 \mathrm{~kg}$ each of Azospirillum and Azotobacter ha ${ }^{-1}$.

\section{Experimental management}

The field was thoroughly prepared with the help of a cultivator followed by using a rotavator to reap the fine tillage. As the station is having a hilly and sloppy area, the specific size raise beds were prepared across the slope.

The required amount of inorganic and organic fertilizers had been applied as consistent with the formulated treatment mixture at the time of planting. Prior to that precise amount of vermicompost become inoculated with biofertilizers like Azospirillum and Azotobacter for 48 hours in partial shade condition. 
Healthy rhizomes visibly loose from disorder and pests with uniform size and weight had been used as the planting materials. The seed rhizomes were first treated with $0.3 \%$ solution of Dithane M-45 and ultimately planted with a spacing of $30 \mathrm{~cm} \times 25 \mathrm{~cm}$ on a sizeable raised bed of $6 \mathrm{~m} \times 1 \mathrm{~m}$ during the month of June. Immediate after planting the rhizomes were blanketed with soil followed by mulching of dry leaves of silver oak to make sure exact and healthy germination.

However, at some stage in tiller improvement stage, the reapplication of dry leaf mulches was executed after one hand weeding, to guard the crop from weed competition. All other cultural operations till the harvest of the crop have been followed uniformly to acquire a healthy crop production. The vegetative growth parameters like plant height $(\mathrm{cm})$, wide variety of tillers in lines with clump and variety of leaves per tiller were manually recorded by way of the usage of the measuring scale.

At maturity the dried above-floor portion (shoot) was removed before harvest leaving underground rhizomes, to permit the rhizome until mature. The rhizomes had been harvested by means of digging and allowed for the field drying in open field conditions. The rhizomes have been nicely washed to eliminate the soil particles. Soon after the cleansing the fresh rhizome yields together with other yield attributed parameters were recorded by the usage of the electronic virtual balance.

\section{Statistical analysis}

The information recorded on different vegetative growth parameters in conjunction with yield and yield attributing parameters were subjected to statistical analysis and treatment mean had been in comparison at a $5 \%$ level of probability (Gomez \& Gomez, 1984).

\section{Benefit-cost ratio}

The expenses of the inputs in rupees prevailing during the experimentation period were considered out the cost of cultivation. Net returns per hectare had been calculated with the aid of deducting the cost of cultivation from gross return. The benefit-cost ratio turned into worked out as follows.

Benefit-cost ratio $=\frac{\text { Net retums (Rs.) per ha }}{\text { cost of cultivation (Rs.) per ha }}$

\section{Results and Discussion}

Results from the three years pooled data as in table 1 revealed significant variations among all the nutrient combinations. Optimum vegetative growth including highest plant height of $128.8 \mathrm{~cm}$, maximum 3.8 tillers per clump and 6.7 leaves per tiller were recorded with the application of $100 \%$ recommended dose of fertilizers together with vermicompost and biofertilizer i.e. $\mathrm{T}_{6}$ followed by the only application of $100 \% \mathrm{RDF}$ i.e. $\mathrm{T}_{10}$ and $75 \%$ RDF along with vermicompost and biofertilizer i.e. $\mathrm{T}_{5}$ with $126.4 \mathrm{~cm}$ of plant height, 3.1 tillers per clump, 6.0 leaves per tiller and $123.4 \mathrm{~cm}$ of plant height, 2.9 tillers per clump, 5.8 leaves per tiller respectively. Here chemical fertilizers by itself and in mixture with organic manures express their superiority among all other treatments. But relatively the incorporation of organic manures additionally expressed their effect on the vegetative growth of turmeric.

The vegetative growth in turmeric flora found better due to the utility of chemical fertilizers in conjunction with biofertilizer and vermicompost. Roy et al., (2011) reported vermicompost contains $3 \%$ of $\mathrm{N}, 1 \% \mathrm{P}_{2} \mathrm{O}_{5}$ and $1.5 \% \mathrm{~K}_{2} \mathrm{O}$. Nitrogen is responsible for photosynthesis, cell division and differentiation, growth and somatic embryogenesis, production of chlorophyll 
content, anthocyanin and the proteins essential for the metabolic procedures that occur during plant growth (Theunissen et al., 2010). Phosphorous is dependable for the increase in water-use effectiveness which is a basic factor for plant productivity in drier atmospheres (Vance 2001; Wittenmayer and Merbach, 2005). Phosphorous improves leaf development, axillary bud development and shoot canopy, by improving photosynthetic surface area and carbohydrate utilization (Ahloowalia et al., 2004). Potassium is accountable for a numerous physiological procedures essential for plant growth, including the support for plant water equalization and protein synthesis (Theunissen et al., 2010). Hence the vegetative growth in turmeric plants might be because of the fine feasible absorption of primary nutrients from chemical fertilizers at the side of the steady supplementations of other nutrient contents from additional assets like vermicompost and biofertilizers.

A similar trend was observed with reference to number of primary fingers per clump as well as the weight of primary fingers per clump. The utmost number of primary fingers (5.6) and weight of primary fingers $(99.8 \mathrm{~g}$ ) were recorded with the appliance of $100 \%$ chemical fertilizers with vermicompost and biofertilizer $\left(\mathrm{T}_{6}\right)$ followed by the only application of $100 \%$ chemical fertilizer $\left(\mathrm{T}_{10}\right)$ with 4.9 primary fingers and $85.5 \mathrm{~g}$ weight of primary fingers and $75 \%$ chemical fertilizers along with vermicompost and biofertilizer $\left(\mathrm{T}_{5}\right)$ with the 4.7 number of primary fingers and $82.1 \mathrm{~g}$ weight of primary fingers.

Maximum 7.6 numbers of secondary fingers with $77.3 \mathrm{~g}$ weight were recorded with the application of $100 \%$ chemical fertilizers along with vermicompost and biofertilizers followed by the application of $75 \%$ chemical fertilizers along with vermicompost and biofertilizers that produced 7.1 secondary fingers with $70.0 \mathrm{~g}$ weight and sole application of $100 \%$ of chemical fertilizers with 6.5 secondary fingers of $63.7 \mathrm{~g}$ weight. The only application of chemical fertilizers could not ready to express its efficacy over the mixture of chemical fertilizers and organic manures during the formation of secondary fingers. It had been presumed that organic manure like vermicompost and biofertilizers played a crucial role within the formation of secondary fingers during reproductive stage.

An identical trend was also recorded for the rhizome yield. Application of $100 \%$ chemical fertilizers along with vermicompost and biofertilizers recorded the very best rhizome yield of $219.2 \mathrm{q} \mathrm{ha}^{-1}$ with the cost of cultivation Rs.5,07,485 ha ${ }^{-1}$, net monetary return Rs.5,88,682 $\mathrm{ha}^{-1}$ and $\mathrm{B}: \mathrm{C}$ ratio 2.16 followed by application of $75 \%$ chemical fertilizers along with vermicompost and biofertilizers with rhizome yield of $206.6 \mathrm{q}$ $\mathrm{ha}^{-1}$, cost of cultivation Rs.5,06,389 $\mathrm{ha}^{-1}$, net monetary return Rs.5,26,644 ha $\mathrm{ha}^{-1}$ and B:C ratio 2.04 and sole application of $100 \%$ chemical fertilizers with rhizome yield of $196.9 \mathrm{q} \mathrm{ha}^{-1}$, cost of cultivation Rs.4,57,791 $\mathrm{ha}^{-1}$, net monetary return Rs.5,26,459 $\mathrm{ha}^{-1}$ and $\mathrm{B}: \mathrm{C}$ ratio 2.15 .

Because the rhizome yield and net monetary return were higher with the application of $75 \%$ chemical fertilizers along with vermicompost and biofertilizers as compared to sole application of $100 \%$ chemical fertilizers, it had been advised to go with application of $75 \%$ chemical fertilizers along with vermicompost and biofertilizers although the cost of cultivation was less and $\mathrm{B}: \mathrm{C}$ ratio was higher with the only application of $100 \%$ chemical fertilizers considering the upkeep of soil health and sustainability in production with the replacement of $25 \%$ chemical fertilizers by organic nutrients. 
Table.1 Growth, yield and economics of turmeric (cv. Roma) influenced by inorganic and organic nutrients over three years (Pooled data)

\begin{tabular}{|c|c|c|c|c|c|c|c|c|c|c|c|c|}
\hline \multirow[t]{2}{*}{ Treatment Details } & 1 & 2 & 3 & 4 & 5 & 6 & 7 & 8 & 9 & 10 & 11 & 12 \\
\hline & $\begin{array}{c}\text { Plant } \\
\text { height } \\
(\mathbf{c m})\end{array}$ & $\begin{array}{l}\text { No. of } \\
\text { tillers } \\
\text { clump } \\
1\end{array}$ & $\begin{array}{l}\text { No. of } \\
\text { leaves } \\
\text { tiller }^{-1}\end{array}$ & $\begin{array}{l}\text { No. of } \\
\text { primary } \\
\text { finger }\end{array}$ & $\begin{array}{c}\text { Wt. of } \\
\text { primary } \\
\text { finger(g) }\end{array}$ & $\begin{array}{l}\text { No. of } \\
\text { secondary } \\
\text { finger }\end{array}$ & $\begin{array}{c}\text { Wt. of } \\
\text { secondary } \\
\text { finger }(g)\end{array}$ & $\begin{array}{c}\text { Rhizome } \\
\text { yield } \\
\left(\mathbf{q} \mathbf{h a}^{-1}\right)\end{array}$ & $\begin{array}{c}\text { Cost of } \\
\text { cultivation } \\
\left(\text { Rs. ha }{ }^{-1}\right)\end{array}$ & $\begin{array}{l}\text { Gross } \\
\text { monetary } \\
\text { return } \\
\left(\text { Rs. ha }{ }^{-1}\right)\end{array}$ & $\begin{array}{l}\text { Net } \\
\text { monetary } \\
\text { return } \\
\left(\text { Rs. ha } \text { ha }^{-1}\right)\end{array}$ & $\begin{array}{l}\mathrm{B}: \mathrm{C} \\
\text { ratio }\end{array}$ \\
\hline $\begin{array}{l}\mathrm{T}_{1} \text {-Control (No } \\
\text { Fertilizer) }\end{array}$ & 104.0 & 2.1 & 4.0 & 2.4 & 54.6 & 4.2 & 39.4 & 133.7 & 445611 & 668417 & 222806 & 1.50 \\
\hline $\begin{array}{l}T_{2-0 \% R D F}+\mathrm{VC}(5 \mathrm{t} \\
\left.\mathrm{ha}^{-1}\right)+\mathrm{BF}\end{array}$ & 103.7 & 2.2 & 4.2 & 3.2 & 57.9 & 5.2 & 46.0 & 156.9 & 496466 & 784417 & 287950 & 1.58 \\
\hline $\begin{array}{l}\mathrm{T}_{3}-25 \% \mathrm{RDF} \\
+\mathrm{VC}+\mathrm{BF}\end{array}$ & 113.9 & 2.3 & 4.5 & 3.5 & 63.9 & 5.8 & 52.0 & 171.8 & 507353 & 862500 & 355147 & 1.70 \\
\hline $\begin{array}{l}\mathrm{T}_{4}-50 \% \mathrm{RDF} \\
+\mathrm{VC}+\mathrm{BF}\end{array}$ & 116.6 & 2.6 & 5.1 & 4.4 & 68.1 & 6.1 & 59.7 & 190.4 & 506294 & 951833 & 445539 & 1.88 \\
\hline $\begin{array}{l}\mathrm{T}_{5}-75 \% \mathrm{RDF} \\
+\mathrm{VC}+\mathrm{BF}\end{array}$ & 123.4 & 2.9 & 5.8 & 4.7 & 82.1 & 7.1 & 70.0 & 206.6 & 506389 & 1033033 & 526644 & 2.04 \\
\hline $\begin{array}{l}\mathrm{T}_{6}-100 \% \mathrm{RDF} \\
+\mathrm{VC}+\mathrm{BF}\end{array}$ & 128.8 & 3.8 & 6.7 & 5.6 & 99.8 & 7.6 & 77.3 & 219.2 & 507485 & 1096167 & 588682 & 2.16 \\
\hline $\mathrm{T}_{7}-25 \% \mathrm{RDF}$ & 113.4 & 2.2 & 4.1 & 2.8 & 63.9 & 5.2 & 48.8 & 158.8 & 453762 & 794083 & 340321 & 1.75 \\
\hline $\mathrm{T}_{8}-50 \% \mathrm{RDF}$ & 116.9 & 2.2 & 4.7 & 3.4 & 67.3 & 5.9 & 51.4 & 167.6 & 455435 & 838000 & 382565 & 1.84 \\
\hline $\mathrm{T}_{9}-75 \% \mathrm{RDF}$ & 122.3 & 2.5 & 5.4 & 4.5 & 75.7 & 6.6 & 59.4 & 182.8 & 456917 & 913833 & 456917 & 2.00 \\
\hline $\begin{array}{l}\mathrm{T}_{10-100 \% \mathrm{RDF}} \\
\left(60: 30: 90 \mathrm{~kg} \mathrm{~N}, \mathrm{P}_{2} \mathrm{O}_{5},\right. \\
\left.\quad \mathrm{K}_{2} \mathrm{O} \mathrm{ha}^{-1}\right)\end{array}$ & 126.4 & 3.1 & 6.0 & 4.9 & 85.5 & 6.5 & 63.7 & 196.9 & 457791 & 984250 & 526459 & 2.15 \\
\hline SE $(m) \pm$ & 3.6 & 0.2 & 0.3 & 0.2 & 3.6 & 0.4 & 2.8 & 2.3 & & & & \\
\hline $\mathrm{CD}(\mathrm{P}=0.05)$ & 10.6 & 0.5 & 0.8 & 0.6 & 10.7 & 1.3 & 8.3 & 6.8 & & & & \\
\hline
\end{tabular}

*RDF-Recommended Dose of Fertilizer, BF-Bio-fertilizers and VC-Vermicompost. 


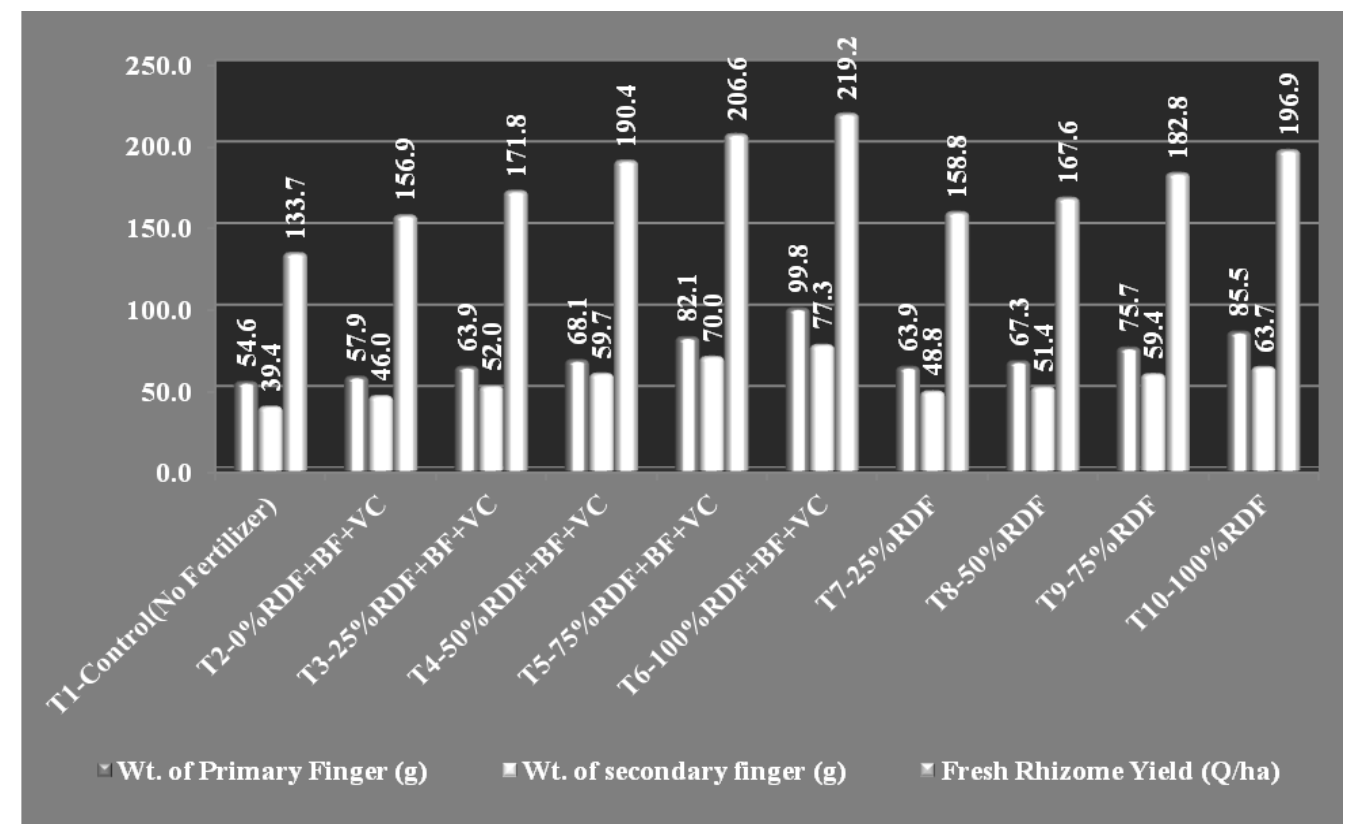

Fig.1 Yield of turmeric (cv. Roma) influenced by inorganic and organic nutrients

The results support the findings obtained by Roy et. al., (2011), they elaborate the application of vermicompost along with Azospirillum and Arbuscular mycorrhiza was found to be most effective in producing highest turmeric yield. Atiyeh et al., (2000) reported vermicompost are the organic manures characterized by high porosity, aeration, drainage, water holding capacity and microbial activity.

Adequate air circulation with high porosity and optimum water holding capacity encourage the rhizome development below the soil surface. Furthermore, Boraste et al., (2009) reported bio-fertilizers improve the crop yield as well as soil nutrient status by providing most favourable nutrient accessibility to crop plant by fixing atmospheric nitrogen and dissolving soil phosphorous.

Results obtained by (Isaac and Varghese, 2016) also evident the present findings, they observed that highest rhizome yield of $42.71 \mathrm{t}$ $\mathrm{ha}^{-1}$ recorded in treatment receiving vermicompost in conjunction with chemical fertilizers followed by the aid of poultry manure substitution (33.08 $\mathrm{t} \mathrm{ha}^{-1}$ ) and sole organics - integration of vermicompost enrich with PGPR mix with poultry manure and goat manure $\left(31.61 \mathrm{t} \mathrm{ha}^{-1}\right)$ in a field trial carried out in an integrated farming system at Farming System Research Station, Kerala Agricultural University, Sadanandapuram, Kerala.

It had been also observed that chemical fertilizers alone expressed their superiority as compared to the mixture of both chemical and organic nutrients. It had been evident that the application of $100 \%$ chemical fertilizers might be replaced with the application of $75 \%$ chemical fertilizers with vermicompost and bio-fertilizers. Replacement of $25 \%$ chemical fertilizers with organic nutrients would help within the maintenance of soil health without affecting crop growth.

The results recorded by Amala et al., (2019) corroborate the present findings, with highest $29.69 \mathrm{t} \mathrm{ha}^{-1}$ of fresh rhizome yield by the 
application of $75 \%$ (Recommended dose of fertilizer) + Farm Yard Manure $\left(25 \mathrm{t} \mathrm{ha}^{-1}\right)+$ Vermicompost $\left(5 \mathrm{t} \mathrm{ha}^{-1}\right)+$ Neem cake $(500 \mathrm{~kg}$ $\left.\mathrm{ha}^{-1}\right)+$ Azotobacter $\left(2 \mathrm{~kg} \mathrm{ha}^{-1}\right)+$ Phosphorous Solubilizing Bacteria $\left(2 \mathrm{~kg} \mathrm{ha}^{-1}\right)$.

It was concluded that application of biofertilizers and vermicompost alongside either $100 \%$ or $75 \%$ chemical fertilizers would be the best inorganic and organic nutrient combination to get an honest economic yield in turmeric with an objective to take care of the soil health and sustainability in production under eastern ghat high land zone of Odisha.

\section{Acknowledgement}

We gratefully acknowledge the financial and logistic support of Odisha University of Agriculture and Technology, Bhubaneswar, Odisha, India in conducting the research works.

\section{References}

Ahloowalia, B.S., Malusznyski, M., Nichterlin, K. 2004. Global impact of mutation derived varieties. Euphytica, 135: 187204.

Aira, M., Monroy, F., Dominguez, J., Mato, S. 2002. How earthworm density affects microbial biomass and activity in pig manure. European Journal of Soil Biology. 38: 7-10.

Amala, D., Neeraja prabhakar, B., Padma, M., and Triveni, S., 2019. effect of integrated nutrient management on yield, quality and economics of turmeric (Curcuma longa L.) var IISR Pragathi. Journal of Pharmacognosy and Phytochemistry. Pp3112 - 3114

Anonymous. 2015. Souvenir \& Abstracts, National Symposium on Spices and Aromatic Crops (SYMSAC VIII). Towards 2050 - Strategies for Sustainable Spices Production. Organized by Indian
Society for Spices, Kozhikode, Kerala and Tamil Nadu Agricultural University, Coimbatore, Tamil Nadu on 16-18 December 2015, P-3-4.

Anonymous. 2016. Area, production and productivity of various kinds of spices. Horticulture - Statistical Year Book India 2016. http://www.mospi.gov.in/statisticalyear-book-india/2016/178.

Anuradha, U. B., Patil, S. S., Kurubar, A. R., Ramesh, G., and Hiregoudar, S., 2018. Effect of integrated nutrient management on growth and yield of turmeric (Curcuma longa L.) cv Salem. International Journal of Current Microbiology and applied Sciences. PP3196-3203.

Atiyeh, R.M., Subler, S., Edwards, C.A., Bachman, G., Metzger, J.D., Shuster, W. 2000. Effects of vermicomposts and composts on plant growth in horticultural container media and soil. Pedobiologia (Jena), 44: 579-590.

Bejar, E. 2018. Turmeric (Curcuma longa). Botanical Adulterants Bulletins. www.botanicaladulterants.org.

Boraste, A., Vamsi, K. K., Jhadav, A., Khairnar, Y., Gupta, N., Trivedi, S., Patil, P., Gupta, G., Gupta, M., Mujapara, A. K., Joshi, B. 2009. Bio-fertilizers: A novel tool for agriculture. International Journal of Microbiology Research, 1, (2):23-31.

Chanchan, M., Thapa, P. and Hore, J. K. 2018. Effect of bio-fertilizers with graded levels of nitrogen and phosphorus on growth and yield of garlic (Allum sativum L.).Research on Crops.19 (1):127-131.

Gomez, K. A., Gomez, A. A. 1984. Statistical Procedures in Agricultural Research. John Wiley, New York.

Isaac, S. R., and Varghese, J. 2016. Nutrient management in turmeric (Curcuma longa L.) in an integrated farming system in southern Kerala. Journal of spices and Aromatic Crops. Vol.25 (2):206-209.

Jayanthi, C., Vannila, C., Nalini, K., \& Chandrasekaran, K. 2009. Sustainable integrated management of crop with allied enterprises - Ensuring livelihood 
security of small and marginal farmers. Tech Monitor. Jan-Feb, P.21-29.

Patel, P. P., Jadav, R. G., and Parmar, A. B. 2010. Efficiency of mutimicronutrient on growth, yield and quality of brinjal (Solanum melongena L.) cv. Gujarat Oblong Brinjal-1, Asian journal of Horticulture. 5; 36-39.

Peter, K. V., Srinivasan, V., \& Hamza, S. 2000. Nutrient management in spices. Fertilizers News 45: 13-18.

Roy, S. S., Hore, J. K., Prakash, N., Sharma, P.K., and Adak, T. 2011. Influence of organic manures and microbial inoculants on yield and leaf nutrient status of turmeric (Curcuma longa). Journal of Medicinal and Aerometric Plant Sciences. 33(3)349-354.

Sallaku, G., Babaj, I., Kaciu, S., Balliu, A. 2009. The influence of vermicompost on plant growth characteristics of cucumber (Cucumis sativus L.) seedlings under saline conditions. Journal of Food Agriculture and Environment. 7(3-4): 869-872.

Sasikumar, B. 2005. Genetic resources of Curcuma diversity, characterization and utilization. Plant genetic resourcesConserve, Utilize. 3; 130-151.

Saxena, M., Bhattacharya, S., \& Malhotra, S. K. 2016. State wise area and production of turmeric. Horticultural Statics at a glance 2015 (pp. 225-255). Horticultural Statics Division, Department of Agriculture, Cooperation \& Family Welfare, Ministry of Agriculture \& Farmers Welfare, Govt. of India.

Singh, R., and Sinsinwar, B. S., 2006. Effect of integrated nutrient management on growth, yield, oil content and nutrient uptake of Indian mustard. Indian Journal of Agricultural Sciences.76:322-324.

Srinivas, P., Nirmala, G., Bhavani, S., and Sindhu, K. 2018. Post-harvest practices, processing and value addition of turmeric. Advances in post-harvest management, processing and value addition of Horticultural crops, Vegetables, spices and plantation crops (part-2). (Ed. J C jana, T K koley, A Mani, C Karak and D K Murmu).Today \& Tomorrow's printers and Publishers, 4436/7, Ansari Road, Daryaganj, NewDelhi-110002.P-399.

Theunissen, J., Ndakidemi, P. A., and Laubscher, P. C., 2010. Potential of vermicompost produce from plant waste on the growth and nutrient status in vegetable production. International Journal of Physical Sciences. 5(13)19641973.

Vance, C.P., 2001. Symbiotic nitrogen fixation and phosphorus acquisition. Plant Nutrition in a world of declining renewable resources. Plant Physiology. 127: 390-397.

Wittenmayer, L., Merbach, W. 2005. Plant responses to drought and phosphorus deficiency: contribution of phytohormones in root-related processes. Journal of Plant Nutrition and Soil Science. 168(4): 531-540.

\section{How to cite this article:}

Bibhuti Bhusan Sahoo, Bibhuti Bhusan Dalei, Amit Phonglosa and Niranjan Senapati. 2020. Aptitude of Vermicompost and Bio-fertilizers on Crop Growth, Yield and Economics of Turmeric (Curcuma longa L.). Int.J.Curr.Microbiol.App.Sci. 9(06): 138-146. doi: https://doi.org/10.20546/ijcmas.2020.906.018 